УДК 343.241 .4

DOI https://doi.org/10.32837/apdp.v0i86.2414

М.Г. Корабель

\title{
ПРАВОВЕ РЕГУЛЮВАННЯ ЗАСТОСУВАННЯ ВИПРАВНИХ РОБІТ ЩОДО ОКРЕМОГО КОЛА ОСІБ
}

Покарання є одним із центральних інститутів кримінального права та важливим інструментом у руках держави для охорони найбільш значущих суспільних відносин. Воно є головною і найбільш поширеною формою реалізації кримінальної відповідальності, у покаранні виражається від імені держави негативна оцінка вчиненого злочину й особи злочинця. Покарання повинно відповідати тяжкості вчиненого злочину, бути справедливим і достатнім для виправлення засудженого та запобігання вчиненню нових злочинів. Тільки таке покарання сприймається винним та іншими особами як кінцевий і достатній результат скоєного злочинного діяння.

Пошук альтернативних видів покарань, які не пов’язані з ізоляцією особи від суспільства, є актуальним питанням для світового співтовариства, це зумовлено негативними наслідками соціального, правового та морального характеру, що настають для осіб, яка відбувають покарання у виді позбавлення волі.

Виправні роботи відповідають поставленим вище вимогам і $є$ альтернативним видом покарання, яке не пов'язане з ізоляцією особи від суспільства, не утворює зазначених негативних наслідків. Але відсутність усебічного правового регулювання зумовлює необхідність комплексного аналізу досліджуваного покарання.

У сучасній вітчизняній кримінально-правовій науці питання даного покарання досліджувалися в роботах Ю.В. Бауліна, І.Г. Богатирьова, І.А. Вартилецької, Н.О. Гуторової, Т.А. Денисової, В.П. Козирєвої, Ю.А. Пономаренка, В.В. Сташиса, В.М. Трубнікова, О.В. Ткачової та деяких інших науковців. Однак значна кількість питань щодо правової природи досліджуваного виду покарання залишається дискусійними. Це зумовлює потребу зробити власний правовий аналіз виправних робіт як покарання, яке не пов'язане з ізоляцією особи від суспільства, з метою вдосконалення практики призначення та виконання досліджуваного покарання.

Актуальність теми пропонованої статті зумовлена необхідністю наукового

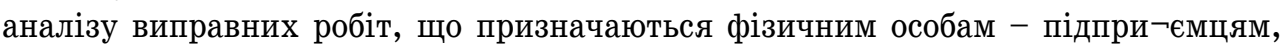
оскільки зазначені особи не передбачені в ч. 2 ст. 57 Кримінального кодексу України, що суперечить національному законодавству. А також неможливістю призначення досліджуваного покарання безробітним особам.

У системі покарань Кримінальний кодекс (далі - КК) України відносить виправні роботи до числа основних, кількість яких у санкціях статей поступово збільшувалась. Так, за КК Української Соціалістичної Радянської Республіки (далі - УСРР) 1922 р. вони як покарання в санкції передбачалися в 74 статтях, за КК Російської Соціалістичної Федеративної Радянської Республіки (далі РСФРР) 1922 г. - у 54 статтях, у КК УСРР 1927 р. їх налічувалося вже 75, у КК РСФРР 1926 р. - 78, а у КК України 1960 р. (станом на початок 2001 р.) кількість 
таких статей становила вже понад 150 [14, с. 56]. Зараз (станом на початок 2020 р.) у чинному КК України виправні роботи передбачені в санкціях 102 складів злочинів. У зв'язку зі змінами в політичному, економічному, соціальному та культурному житті держави виникла потреба в удосконаленні досліджуваного покарання для відповідності сучасним умовам розвитку суспільства. А саме розширенню кола осіб, до яких не можуть застосовуватись виправні роботи.

У науковій роботі О.В. Ткачова звертає увагу на проблеми співвідношення виправних робіт і примусової праці та пропонує звернутися до історії становлення міжнародного законодавства про заборону примусової праці. У 1930 р. Генеральною конференцією Міжнародної організації праці (далі - МОП) ухвалено Конвенцію про примусову працю, у п. «с» ст. 2 якої зазначалося, що термін «примусова чи обов’язкова праця» не включає будь-яку роботу або службу, що вимагається від певної особи внаслідок вироку, винесеного рішенням судового органу, за умови, якщо ця робота або служба провадитиметься під наглядом і контролем державної влади і якщо вказану особу не буде віддано чи передано в розпорядження приватних осіб, компаній чи громад [11, с. 19]. У 1957 р. Генеральна конференція МОП на сороковій сесії ухвалила Конвенцію про скасування примусової праці. У цьому документі йдеться про те, що «будь-який член Міжнародної організації праці, що ратифікував зазначену Конвенцію, зобов'язується скасувати примусову чи обов'язкову працю і не вдаватися до будь-якої її форми: а) як засіб політичного впливу, чи виховання, чи як міра покарання за наявності або вираження політичних поглядів чи переконань, які суперечать установленій політичній, соціальній або економічній системі; б) як засіб підтримання трудової дисципліни» [33, с. 9]. Водночас терміном «примусова чи обов'язкова праця», згідно зі ст. 4 Європейської конвенції про захист прав людини і основоположних свобод 1950 р., не охоплюється будьяка робота, виконання якої зазвичай вимагається під час ув'язнення людини після iї засудження [14, с. 36]. Убачається доцільним звернути увагу на ч. 1 ст. 57 КК України: «Покарання у виді виправних робіт встановлюється на строк від шести місяців до двох років і відбувається за місцем роботи засудженого. Із суми заробітку засудженого до виправних робіт провадиться відрахування в доход держави у розмірі, встановленому вироком суду, у межах від десяти до двадцяти відсотків» [9, с. 54]. Отже, виправні роботи відбуваються за місцем роботи засудженого, що дозволяє зберегти соціальні зв'язки особи, не потрібен процес ресоціалізаціі після відбування покарання, пов'язаного з ізоляцією. Досліджуваний вид покарання, хоч і належить до числа майнових покарань, але, на відміну від штрафу, покладає на засудженого обов'язок упродовж певного проміжку часу мати постійне місце роботи. Що допомагає досягти поставлених перед покаранням цілей, а саме виправлення засудженого. Наведене дозволяє дійти висновку, що є неправильним співвідношення примусової чи обов'язкової праці та виправних робіт.

$\mathrm{y}$ науковій статті вбачається доцільним проаналізувати запропонований у ст. 57 КК України перелік осіб, до яких досліджуване покарання не застосовується.

Ч. 2 ст. 57 КК України передбачає виключний перелік осіб, до яких виправні роботи не застосовуються: до вагітних жінок та жінок, які перебувають у відпустці 
по догляду за дитиною, до непрацездатних, до осіб, що не досягли шістнадцяти років, та тих, що досягли пенсійного віку, а також до військовослужбовців, осіб рядового і начальницького складу Державної служби спеціального зв'язку та захисту інформації України, працівників правоохоронних органів, нотаріусів, приватних виконавців, суддів, прокурорів, адвокатів, державних службовців, посадових осіб органів місцевого самоврядування [9, с. 34].

Необхідно звернути увагу на те, що в зазначеному переліку не вказані безробітні та фізичні особи - підприємці, що суперечить Господарському кодексу України. $\mathrm{У}$ національному законодавстві на безробітних осіб не покладено обов'язку пошуку місця роботи, оскільки це є правом осіб за Конституцією України. Відсутність постійного місця роботи унеможливлює відрахування в доход держави коштів у розмірі, встановленому вироком суду, у межах від десяти до двадцяти відсотків.

Проведемо аналогію із ч. 2 ст. 100 КК України, де зазначено: «Виправні роботи можуть бути призначені неповнолітньому у віці від 16 до 18 років за місцем роботи на строк від двох місяців до одного року» [9, с. 56]. Ужите у статті словосполучення «можуть бути призначені $<$...> за місцем роботи» дає суду право призначати виправні роботи в разі наявності постійного місця роботи неповнолітнього. Тобто досліджуване покарання не призначається неповнолітнім, що не мають постійного місця роботи.

3 наведеного можна зробити висновок, що ч. 2 ст. 57 КК України, яка передбачає виключний перелік осіб, до яких виправні роботи не застосовуються, має бути доповнена зазначенням безробітних осіб.

Відповідно до ст. 128 Господарського кодексу (далі - ГК) України, яка визначає статус громадян як суб’єктів господарювання, громадянин-підприємець здійснює свою діяльність на засадах сво-боди підприємництва та відповідно до принципів, передбачених у ст. 44 ГК України, а саме:

1) вільного вибору підприємцем видів підприємницької діяльності;

2) самостійного формування підприємцем програми діяльності, вибору постачальників і споживачів продукції, що виробляється, залучення матеріально-технічних, фінансових та інших видів ресурсів, використання яких не обмежено законом, встановлення цін на продукцію та послуги відповідно до закону;

3) вільного найму підприємцем працівників; комерційного розрахунку та власного комерційного ризику;

4) вільного розпорядження прибутком, що залишається в підприємця після сплати податків, зборів та інших платежів, передбачених законом;

5) самостійного здійснення підприємцем зовнішньоекономічної діяльності, використання підприємцем належної йому частки валютної виручки на свій розсуд [6, с. 45].

У результаті проведеного аналізу Господарського кодексу України, Кримінально-виконавчого кодексу України та Закону України «Про пробацію» [7, с. 4] вбачається необхідним внести зміни до ч. 2 ст. 57 КК України, доповнити зазначений перелік «<...> безробітні особи та фізичні особи - підприємці» .

Проведений у науковій статті правовий аналіз досліджуваного покарання дозволяє зробити висновки, що виправні роботи є альтернативним видом покарань, 
що не пов'язані з ізоляцією особи від суспільства. Прирівнювати досліджуване покарання до примусової праці недоцільно, що підтверджує необхідність існування виправних робіт у системі покарань України.

$\mathrm{V}$ науковій статті розглянуто та запропоновано узгодження національного законодавства із ч. 2 ст. 57 КК України, що необхідно для призначення та виконання виправних робіт як основного виду покарання щодо окремого кола осіб.

\section{Jimepamypa}

1. Баулін Ю.В. Виправні роботи у проєкті КК України. Проблеми пенітенціарної теорії і практикu. 2001. № 6. С. 199-203.

2. Богатирьов І.Г. Виправні роботи як вид покарань: кримінальні, кримінологічні та кримінально-виконавчі проблеми. Київ : МП «Леся», 2002. 139 с.

3. Богатирьов І.Г., Халимон С.І. Кримінально-виконавча інспекція як суб’єкт запобігання злочинам : монографія. Харків : Харків юрид., 2009. 320 с.

4. Вартилецька I.А. Примусові роботи в системі кримінальних покарань: Iсторія та сучасність. Матеріали науково-практичної конференції, Київ, 25-26 травня 1995 р. Київ : РВВ КІВС при УАВС, 1996. C. $124-130$.

5. Вербенський М.Г. Покарання, не пов'язані з позбавленням волі : загальна характеристика і проблеми застосування. Новий Кримінальний кодекс Украӥни : Питання застосування $і$ вивчення : матеріали Міжнародної науково-практичної конференції, Харків, 25-26 жовтня 2001 р. / В.В. Сташис (гол. ред.) та ін. Київ ; Харків : Юрінком-Інтер, 2002. С. 86-89.

6. Господарський кодекс України від 16 січня 2003 р. № 436-IV (редакція станом на 16 липня 2020 p.).

7. Про пробацію : Закон України від 5 лютого 2015 р. № 160-VIII.

8. Конституція України : Закон від 28 червня 1996 р. Відомості Верховної Ради України. 1996. № 30. Ст. 141.

9. Кримінальний кодекс України : Закон від 5 квітня 2001 р. № 2341-III (редакція станом на 3 липня 2020 p.)

10. Кримінальні покарання в Україні : статистичний огляд / уклад. : О.П. Букалов, М.М. Мінаєв, I.С. Яковець. Донецьк : Донец. меморіал, 2007. 36 с.

11. Конвенція про примусову чи обов’язкову працю № 29. Генеральна Конференція Міжнародної організації праці $1956 \mathrm{p}$.

12. Конвенція про захист прав людини і основоположних свобод. Рим. 04.11.1950.

13. Конвенція про скасування примусової праці № 1051930 p.

14. Ткачова О.В. Виконання покарань у виді виправних і громадських робіт : монографія. Харків : Право, 2010. 192 с. ISBN 978-966-458-210-7.

\section{Анотація}

Корабель М. Г. Правове регулювання застосування виправних робіт щодо окремого кола осіб. Стаття.

Покарання є головною і найбільш поширеною формою реалізації кримінальної відповідальності, у покаранні виражається від імені держави негативна оцінка вчиненого злочину й особи злочинця. Покарання повинно відповідати тяжкості вчиненого злочину, бути справедливим і достатнім для виправлення засудженого та запобігання вчиненню нових злочинів. Тільки таке покарання сприймається винним та іншими особами як кінцевий і достатній результат скоєного злочинного діяння.

Пошук альтернативних видів покарань, які не пов'язані з ізоляцією особи від суспільства, є актуальним питанням для світового співтовариства. Це зумовлено негативними наслідками соціального, правового та морального характеру, що настають для осіб, яка відбувають покарання у виді позбавлення волі. Виправні роботи відповідають поставленим вимогам $і \in$ альтернативним видом покарання, яке не пов'язане з ізоляцією особи від суспільства, не спричиняє зазначених негативних наслідків. Виправні роботи відбуваються за місцем роботи засудженого, що дозволяє зберегти соціальні зв'язки особи, не потребуе ресоціалізаціі, як після відбування покарання, пов'язаного з ізоляцією. Досліджуваний вид покарання, хоч і належить до числа майнових покарань, але, на відміну від штрафу, 
покладає на засудженого обов'язок упродовж певного проміжку часу мати постійне місце роботи. Що допомагає досягти поставлених перед покаранням цілей, а саме виправлення засудженого.

Але відсутність усебічного правового регулювання зумовлює необхідність комплексного аналізу досліджуваного покарання та відмежування понять «виправні роботи» та «примусова праця», що є дискусійним у науковій літературі.

У частині 2 статті 57 Кримінального кодексу України передбачено виключний перелік осіб, до яких виправні роботи не застосовуються. Доцільно звернути увагу на те, що в зазначеному переліку не зазначені безробітні та фізичні особи - підприємці, що суперечить Господарському кодексу України. У науковій статті розглянуто та запропоновано узгодження національного законодавства і частини 2 статті 57 Кримінального кодексу України, що необхідно для призначення та виконання виправних робіт як основного виду покарання щодо окремого кола осіб.

Проведений аналіз чинного законодавства в науковій статті дозволив зробити висновки щодо необхідності внесення змін у Кримінальний кодекс України.

Ключові слова: виправні роботи, примусова праця, застосування покарання, безробітні особи, фізична особа - підприємець.

\section{Summary}

Korabel M. H. Legal regulation of the use of corrective labour towards a particular group of people. Article.

Punishment is the main and most common form of criminal liability and the punishment expresses on behalf of the state a negative assessment of the crime and the identity of the offender. Punishment should be commensurate with the gravity of the crime committed, be fair and sufficient to correct the convicted person and prevent the commission of new crimes. Only such punishment is perceived by the guilty and other persons as the final and sufficient result of the committed criminal act.

The search for alternative types of punishment, not related to the isolation of a person from society, is an urgent issue for the world community, due to the negative social, legal and moral consequences for persons serving sentences of imprisonment. Correctional work meets the requirements and is an alternative type of punishment, not related to the isolation of a person from society, and does not create these negative consequences. Correctional work takes place at the place of work of the convict, which allows to maintain the social ties of the person, bypassing the process of resocialization after serving a sentence related to isolation. Although the type of punishment under investigation is one of the property punishments, unlike the fine, it imposes on the convict the obligation to have a permanent job for a certain period of time. What helps to achieve the goals set before the punishment, namely the correction of the convict.

However, the lack of comprehensive legal regulation necessitates a comprehensive analysis of the studied punishment and the separation of the concepts of "correctional labor" and "forced labor", which is debatable in the scientific literature.

Part 2 of Article 57 of the Criminal Code of Ukraine provides an exclusive list of persons to whom corrective labor is not applied. It is expedient to pay attention that in the specified list there are no unemployed and physical persons - businessmen that contradicts the Commercial code of Ukraine

In the scientific article it was considered and proposed to bring into compliance with national legislation Part 2 of Article 57 of the Criminal Code of Ukraine, which is necessary for the appointment and execution of correctional labor, as the main type of punishment for a certain range of persons.

The analysis of the current legislation in the scientific article allowed to draw conclusions about the need to amend the Criminal Code of Ukraine.

Key words: correctional work, forced labor, punishment, unemployed, entrepreneur. 